\title{
Basil seeds as a source of antioxidants affected by fortification with selenium
}

\author{
Ivana Mezeyovál *, Alžbeta Hegedüsová ${ }^{1}$, Ondrej Hegedüs ${ }^{2}$, \\ Andrea Vargová ${ }^{3}$, Mária Timoracká ${ }^{4}$, Miroslav Šlosár ${ }^{1}$, Alena Andrejiová 1 , \\ Tünde Juríkovás, Ján Mezey ${ }^{6}$
}

\author{
${ }^{1}$ Department of Vegetable Production, Faculty of Horticulture and Landscape Engineering, \\ Slovak University of Agriculture in Nitra, Slovakia \\ ${ }^{2}$ Department of Management, Faculty of Economics, J. Selye University, Slovakia \\ ${ }^{3}$ Department of Chemistry, Faculty of Education, J. Selye University, Slovakia \\ ${ }^{4}$ Department of Chemistry, Faculty of Biotechnology and Food Sciences, Slovak University of Agriculture in Nitra, Slovakia \\ ${ }^{5}$ Institute of Teaching Education, University of Constantinus the Philosopher in Nitra, Slovakia \\ ${ }^{6}$ Department of Fruit Growing, Viticulture and Enology, Faculty of Horticulture and Landscape Engineering, \\ Slovak University of Agriculture in Nitra, Slovakia
}

\begin{abstract}
The work aimed to determine the potential of selenium incorporation into seeds of selected species of Ocimum spp. after fortification with a foliar solution of sodium selenate at a concentration of $50 \mathrm{~g} \mathrm{Se} \cdot \mathrm{ha}^{-1}$. In a 2-year trial, the selenium content was determined by electrothermal atomic absorption method with Zeeman background correction. Modified spectrophotometric method (2,2-diphenyl-1-picrylhydrazyl [DPPH] assays) was used to rate the potential of oxidationreduction components of basil seeds (AA). The total polyphenol content (TPC) was determined spectrophotometrically using the Folin-Ciocalteu reagent and gallic acid (GA) as the standard solution. The results of experiments showed that the selenium biofortification significantly $(p<0.05)$ increased the content of selenium in basil seeds (17-fold increase in comparison with controlled variant in case of Tulsi, 12-fold in 'Cinamonette' and 12-fold in 'Dark Green' when compared with control). The basil seeds represented a valuable source of polyphenols (1414.61-1681.75 $\mu \mathrm{g} \mathrm{GA} \cdot \mathrm{g}^{-1}$ dried weight [d.w.]) with multiple times higher antioxidant activity $\left(23.50-28.97 \mathrm{mmol}\right.$ Trolox $\left.\cdot \mathrm{kg}^{-1}\right)$ in comparison with common tested horticultural crops (e.g. peas, tomato and pumpkin). Significant influence of fortification was not found in AA and TPC values. Fortification was not significantly reflected in AA and TPC values. In addition to its very strong reproductive function, healing and religious purposes, the basil seed is used as a functional food due to its high content of bioactive compounds.
\end{abstract}

Keywords: AOA, fortification, Ocimum, selenium content, TPC

\section{Abbreviations:}

AOA, antioxidant activity; ET-AAS, electrothermal atomic absorption; DM, dry matter; DPPH, 2,2-diphenyl-1picrylhydrazyl; TPC, total polyphenols content.

\section{INTRODUCTION}

Basil (Ocimum spp.) belonging to family Lamiaceae has been used worldwide as one of the most popular culinary herbs. The herb of Ocimum basilicum contains a significant quantity of biological compounds with strong curative properties (Muráriková and Neugebauerová, 2018). Basil is considered as one of the most important 
plants producing essential oils which are also found in seeds. Numerous studies in basil essential oil have been demonstrated for its significant anti-inflammatory, antioxidant, anti-stress and antimicrobial activity (Stanojevic et al., 2017). In addition to its very strong reproductive function, healing and religious purposes, the basil seed is also used as a functional food. Basil seeds represented a very potential health supplement which is enriched with much more nutrients and health beneficial compounds. In many parts of Asia, basil seeds have been frequently used in beverages (sarbath) and ice desserts (Falooda) for aesthetic purpose as well as a source of dietary fibre (Cherian, 2019).

Selenium (Se) has been identified as a cofactor of the enzyme glutathione peroxidase, which is a catalyser in the reduction of peroxides that can damage cells and tissues, and it can act as an antioxidant (Puccinelli et al., 2017). Selenium is incorporated into selenoproteins that have a wide range of pleiotropic effects, ranging from antioxidant and anti-inflammatory effects to the production of active thyroid hormone (Rayman, 2012). Selenoproteins need several cofactors for their synthesis and they depend mainly on Se intake through the diet. Different forms of dietary Se may selectively increase synthesis of specific selenoproteins (Zoidis et al., 2018). Selenoproteins have pivotal significance for optimal human and animal health mainly due to their antioxidant activity (AOA) (EFSA, 2014). The European Recommended Dietary Allowance (RDA) of Se for humans is about $55 \mu \mathrm{g} \cdot$ day $^{-1}$ (Elmadfa et al., 2009).

The addition of nutrients, such as minerals and vitamins, to increase the nutritional value of processed food is called fortification (Gomez-Galera et al., 2010). Biofortification is a process of increasing the density of vitamins and minerals in a crop through plant breeding, transgenic techniques or agronomic practices. Biofortified staple crops, when consumed regularly, will generate measureable improvements in human health and nutrition (Bouis and Saltzman, 2018). Whereas conventional fortification requires artificial additives, biofortification involves the synthesis or accumulation of nutrients by plants at source (Díaz-Gómez et al., 2017). Se supplements include sodium selenate and sodium selenite (inorganic forms) and selenium-enriched yeast, selenomethionine and selenocysteine (organic forms) (Puccinelli et al., 2017). The results of investigations into the physico-chemical properties of different forms of Se have proven that dietary supplementation in the organic form showed higher biological availability than inorganic selenium (Fašiangová et al., 2017). Since selenium (Se) plays a significant role in antioxidant defence, biofortification with $\mathrm{Se}$ is a good way to improve the nutritional quality of sprouts, microgreens (Puccinelli et al., 2019) and other kind of vegetable (Hegedüsová et al., 2015; Hegedűsová et al., 2017; Andrejiová et al., 2019; Smoleń et al., 2016). Se concentrations in plant-derived foods are highly variable due to the genetic variation for $\mathrm{Se}$ accumulation and environmental conditions (Ozkutlu et al., 2011). Based on positive basil herb reaction to biofortification with selenium (Hawrylak-Nowak, 2008; Mezeyová et al., 2016; Mezeyová et al., 2018), our research paper was aimed to clarify how the mechanism of selenium incorporation into the seeds will take place after foliar biofortification with the sodium selenate in selected varieties of the genus Ocimum spp. and whether selenisation affects the content of other biologically active substances such as polyphenols and total AOA. This paper represents unique study because fortification in basil seeds has not been provided yet.

\section{MATERIALS AND METHODS}

\section{Basil varieties characterisation}

The experimental trial was carried out in 2017 and 2018 in the place of the Botanical Garden of the Department of Vegetable Production (Slovak University of Agriculture [SUA] in Nitra). Seed sowing and pre-propagation of plants were carried out in the greenhouse of the Botanical Garden SUA. The seeds were purchased from company Semo s.r.o. The pre-grown seedlings were planted in an area of $20.3 \mathrm{~m}^{2}$. Investigated varieties and species of basil are summarised in Table 1.

\section{Soil-climate characteristics}

The soil type of the experimental area is brown soil to chernozem on loess and loess loams and part along the River Nitra belongs to the area of fluvial soils, where the original soil type was fluvial and fluvial glue (Hreško et al., 2006). Fertilisation of the plants was done based on analysis of the experimental area in every evaluated year (Table 2). During the tested years, the soil from experimental area was analysed from the fertilising point of view by Department of Agro-chemistry and Plant Nutrition (Table 2).

In terms of climatic classification of the region, Nitra is situated in a warm and dry area of Slovakia. The evaluation of experimental years according to climatic normal is given in Tables 3 and 4 .

\section{Organisation of the experiment}

The cultivation of plant material was carried out in accordance with modern agrotechnical practices of basil field cultivation. Seed sowing took place on 8 March 2017 and 15 March 2018 in greenhouse of the Botanical Garden (SUA, Nitra). Planting at the permanent place was carried out on 18 May 2017 and 10 May 2018 into well-prepared soil. Plants were planted in 3 rows of 10 plants per variety with a spacing of $0.35 \times 0.40 \mathrm{~m}$. The crops were cut after planting because of multiple inflorescences creation followed by plant irrigation. Based on the agrochemical analysis of the soil, fertilisation of the plants with ammonium with dolomite $(27 \% \mathrm{~N})$ at dosage $0.4 \mathrm{~kg} \cdot 100 \mathrm{~m}^{-2}$ was carried out in two doses in both experimental years. In the phenological stage of BBCH 61 (10\% of flowering flowers), an aqueous solution of sodium selenate at a concentration of $50 \mathrm{mg} \mathrm{Se} \cdot 1 \mathrm{~m}^{-2}$ was applied foliarly. 
Table 1. Basil varieties characterisation and 1000 seed weight in grams, Nitra, 2018 (photo: Mezeyová)

\begin{tabular}{ll}
$\begin{array}{l}\text { Basil species 'variety'/1000 } \\
\text { seed weight (g) }\end{array}$ & \multicolumn{1}{c}{ Botanical description } \\
\hline $\begin{array}{l}\text { O. tenuiflorum } \\
\text { 'Tulsi'/0.58 g }\end{array}$ & $\begin{array}{l}\text { Plant native to tropical and } \\
\text { subtropical Asia. It is an erect, } \\
\text { much branched subshrub, } \\
\text { 40-70 cm tall with hairy stems } \\
\text { and simple opposite green or } \\
\text { purple leaves that are strongly } \\
\text { scented. Leaves have petioles } \\
\text { and are ovate, up to } 5 \text { cm long } \\
\text { and usually slightly toothed. } \\
\text { The flowers are purplish in } \\
\text { elongate racemes in close } \\
\text { whorls. }\end{array}$ \\
& Picture of the herb
\end{tabular}

O. basilicum Cinnamon basil has a spicy,

'Cinamonette'/1.12 g fragrant aroma and flavour. It contains methyl cinnamate, giving it a flavour reminiscent of cinnamon. It has narrow, slightly serrated, dark green, shiny leaves with reddishpurple veins and produces small, pink flowers. Its stems are dark purple. Cinnamon basil grows to $40-70 \mathrm{~cm}$.

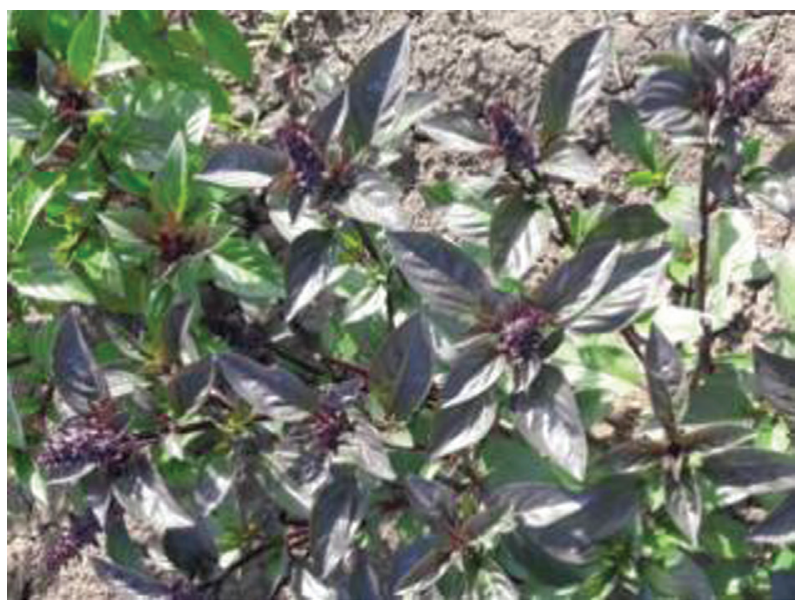

O. basilicum

'Dark Green'/1.28 g
Green leafy variety was bred in Italy. It is an aromatic, annual herb with large oval leaves, dark green-coloured and glossy, serrated. It reaches a height of up to 30 to $60 \mathrm{~cm}$. Erect stem branches well. Inflorescences are white. It is characterised by a biting spicy sweet flavour and taste.

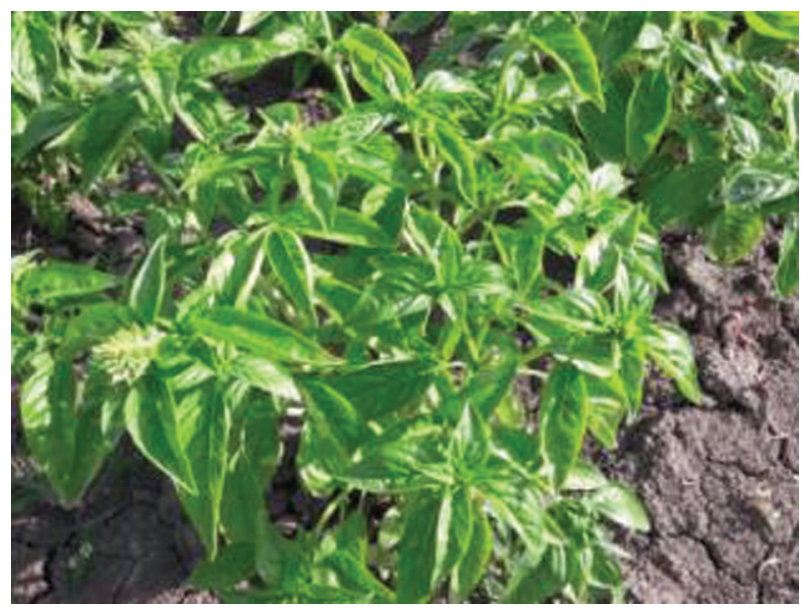

The plants were harvested at the stage of botanical maturity of the seeds (when two-third of the seeds on the plant changed colour from white to dark brown or black) at two different dates, as the varieties ripened gradually. The first harvest took place on 10 August 2017 in case of 'Tulsi' and 'Dark Green' and 'Tulsi', 'Dark Green' and 'Cinamonette' have been cut on 24 August 2017. Manual harvest of the Cinamonette and
Tulsi varieties were carried out on 14 August 2018. The Dark Green variety was harvested on 17 August 2018. Subsequent drying and seed cleaning took place in well-ventilated department stores on dry web fabric.

\section{Reagents and chemicals}

The following reagents were used for the tests: ( \pm )-6-hydroxy-2,5,7,8-tetramethylchromane-2-carboxylic 
Table 2. Soil sample analysis of the experimental area in $\mathrm{mg} \cdot \mathrm{kg}^{-1}$

\begin{tabular}{|c|c|c|c|c|c|c|c|c|}
\hline & \multirow[t]{2}{*}{$\mathrm{pH}$} & \multirow{2}{*}{$\begin{array}{l}\mathrm{N}_{\text {inorganic }} \\
\mathrm{mg} \cdot \mathrm{kg}^{-1}\end{array}$} & \multicolumn{4}{|c|}{ Nutrient content in $\mathrm{mg} \cdot \mathrm{kg}^{-1}$ (Mehl.III) } & \multirow[t]{2}{*}{$\mathrm{S}$} & \multirow{2}{*}{$\begin{array}{c}\% \\
\text { Humus }\end{array}$} \\
\hline & & & $\mathrm{P}$ & $\mathrm{K}$ & $\mathrm{Ca}$ & $\mathrm{Mg}$ & & \\
\hline 2017 & $7.16 \mathrm{~N}$ & $10.0 \mathrm{M}$ & $128.8 \mathrm{H}$ & $567.5 \mathrm{VH}$ & $6000 \mathrm{H}$ & $799.4 \mathrm{VH}$ & $62.5 \mathrm{G}$ & $3.22 \mathrm{G}$ \\
\hline 2018 & $7.04 \mathrm{~N}$ & $6.4 \mathrm{~L}$ & $75.0 \mathrm{M}$ & $368 \mathrm{~V}$ & $6350 \mathrm{H}$ & $763.4 \mathrm{VH}$ & $2.5 \mathrm{VL}$ & $3.29 \mathrm{G}$ \\
\hline
\end{tabular}

Notes: soil pH: N, neutral pH; nutrients: VL, very low content; L, low content; M, medium content; G, good content; H, high content; VH, very high content.

Table 3. Evaluation of months according to temperature climatic normal 1961-1990

\begin{tabular}{lcclcl}
\hline Month & Normal $(1961-1990)$ & $t\left({ }^{\circ} \mathrm{C}\right) 2017$ & Characteristic $(2017)$ & $t\left({ }^{\circ} \mathrm{C}\right) 2018$ & Characteristic $(2018)$ \\
\hline V & 15.1 & 16.6 & Hot & 18.8 & Very hot \\
VI & 18.0 & 21.2 & Extremely hot & 20.7 & Hot \\
VII & 19.8 & 21.7 & Hot & 21.7 & Hot \\
VIII & 19.3 & 22.4 & Extremely hot & 22.5 & Very hot \\
IX & 15.6 & 14.6 & Normal & 16.4 & Normal \\
\hline
\end{tabular}

Table 4. Evaluation of months according to precipitation climatic normal 1961-1990

\begin{tabular}{lcclcl}
\hline Month & Normal (1961-1990) & PRC $(\mathrm{mm}) 2017$ & Characteristic (2017) & PRC (mm) 2018 & Characteristic (2018) \\
\hline V & 58 & 14 & Extremely dry & 29 & Very dry \\
VI & 66 & 26 & Very dry & 44 & Dry \\
VII & 52 & 60 & Normal & 13 & Very dry \\
VIII & 61 & 23 & Very dry & 3 & Extremely dry \\
IX & 40 & 93 & Extremely wet & 55 & Wet \\
\hline
\end{tabular}

acid (Trolox, 97\%, Acros Organics ${ }^{\mathrm{TM}}$, Denmark), 2,2-diphenyl-1-picrylhydrazyl (DPPH, $\leq 100 \%$, Sigma Aldrich), Folin-Ciocalteu reagent (Merck Germany), gallic acid (GA, Sigma Aldrich), sodium carbonate (solution 20\% w/w, Merck Germany), nitric acid $\left(\mathrm{HNO}_{3}\right.$, $67 \%)$, hydrogen peroxide $\left(\mathrm{H}_{2} \mathrm{O}_{2}, 30 \%\right)$, palladium nitrate $\left(\mathrm{Pd}\left(\mathrm{NO}_{3}\right)_{2}\right.$, palladium modifier, $\left.0.1 \mathrm{~mol} \cdot \mathrm{l}^{-1}\right)$, ascorbic acid (AsA, solution 1\%, w/w), methanol (pure pro analysis purity grades of lab reagents, $70 \%$, v/v, Fisher Scientific UK, Loughborough, UK).

\section{Selenium content determination}

Digestion of the plant material took place in the microwave digestion system type CEM Mars X-press (microwave digestion oven). In the digestion container, there was weighed $0.5 \mathrm{~g}$ of the sample. It was wetted with $1 \mathrm{ml}$ double distilled water followed by the addition of $5 \mathrm{ml}$ of concentrated $\mathrm{HNO}_{3}$ and $1 \mathrm{ml}$ of $\mathrm{H}_{2} \mathrm{O}_{2}$. It was digested at $150^{\circ} \mathrm{C}$ for a period of 20 minutes. The digestion product was refilled into volumetric flask till $25 \mathrm{ml}$. Quantitative determination of Se was done by using of ET-AAS method with Zeeman-effect background correction. Atomic absorption spectrometer (SpectrAA240FS Varian, Mulgrave Virginia, Australia) was used to measure the total selenium content. Conditions for selenium measurement were set in the equipment according to the recommendations of the manufacturer for ET-AAS technique (Rothery and Beach, 1988).

\section{Preparation of the extracts}

The average sample was created from the analysed basil seeds (dried at room temperature in clean laboratory conditions of the department of vegetable production) by slicing them into tiny bits and homogenised. Then $1 \mathrm{~g}$ of homogenised mixture and $40 \mathrm{ml}$ of methanol $(70 \%, \mathrm{v} / \mathrm{v})$ were added into $250-\mathrm{ml}$ extraction flasks. They were allowed to stand at room temperature for $20 \mathrm{~h}$ and then extracted with horizontal shaker for 4 h (Melicháčová et al., 2010).

\section{AOA measured by DPPH method}

Determination of AOA was performed with a spectrophotometer Jenway 6301 (Bibby Scientific Ltd., UK) by the method of Hegedüs et al. (2019). DPPH inhibition and spectrophotometric measurements were performed after a constant time of $30 \mathrm{~min}$. Of note, $0.1 \mathrm{ml}$ of the extract was pipetted into the spectrophotometer cuvette (depending on the nature of the sample) and supplemented with $70 \%$ methanol to $2.0 \mathrm{ml}$, and $4 \mathrm{ml}$ of DPPH solution of about $25 \mathrm{mg} \cdot 1^{-1}$ concentration was added. Immediately after the DPPH solution was added, the absorbance of the mixture was measured at $517 \mathrm{~nm}$ $\left(A t_{0}\right)$. Thirty minutes later, the absorbance of each sample was measured at $517 \mathrm{~nm}\left(A t_{30}\right)$. The AOA was calculated based on the following relationship:

a. Expressed as a percentage of DPPH discolouration based on the following relationship: 


$$
\% \mathrm{AOA}=\left(1-\frac{A t_{30}}{A t_{0}}\right) \times 100 \times V_{2} /\left(n \times V_{1}\right)
$$

$\%$ inhibition $\mathrm{AOA} ; A t_{30}$, absorbance of the sample after $30 \mathrm{~min} ; n$, weight of the sample in $\mathrm{g} ; V_{1}$, pipetted volume of the sample $(0.1 \mathrm{ml}) ; V_{2}$, supplemented volume of the extract by methanol (according to the stated method, it is always $2.0 \mathrm{ml}$ ) and $A t_{0}$, the initial sample absorbance value.

b. Expressed as a Trolox equivalent antioxidant capacity (TEAC) calculated from calibration curve. Final value is an average expression of three measurements.

\section{Determination of total polyphenol content}

Total polyphenol content (TPC) was estimated by using Folin-Ciocalteu assay by the method of Lachman et al. (2003) and calculated in milligram of GA equivalent (GAE) per kilogram dried weight (d.w.). GA is generally used as a standard unit for phenolic content determination because of wide spectrum of phenolic compounds. The Folin-Ciocalteu phenol reagent was added to a volumetric flask containing $100 \mu \mathrm{l}$ of extract. The content was mixed and $5 \mathrm{ml}$ of a sodium carbonate solution $(20 \%$, w/w) was added after $3 \mathrm{~min}$. The volume was adjusted to $50 \mathrm{ml}$ by adding distilled water. After $2 \mathrm{~h}$, the samples were centrifuged for $10 \mathrm{~min}$ and the absorbance was measured at $765 \mathrm{~nm}$ of wavelength against blank (spectrophotometer Shimadzu UV/VIS-1240). The concentration of polyphenols was calculated from a standard curve plotted with known concentration of GA.

\section{Statistical analyses}

The analysis of variance (ANOVA), the multifactor analysis of variance (MANOVA) and the multiple range test were carried out using the Statgraphic Centurion XVII (StatPoint Inc., USA).

\section{RESULTS AND DISCUSSION}

\section{Selenium content}

Selenium biofortification with foliar-applied sodium selenate solution in concentration of $5 \mathrm{mg} \mathrm{Se} \cdot 1 \mathrm{~m}^{-2}$ significantly $(p<0.05)$ increased with the content of selenium in basil seeds as shown in Table 5. In 2017, the highest increase in treated variant compared with control was obtained in case of Tulsi basil (from 0.025 to $0.809 \mathrm{mg} \cdot \mathrm{kg}^{-1}$ of Se). In 2018, the similar situation was observed for Dark Green variety with an increase from 0.078 to $0.823 \mathrm{mg} \cdot \mathrm{kg}^{-1}$ of Se. Comparing all data from both tested years (Figure 1), the significant difference $(p<0.05)$ between tested variants was proved. On the other hand, the influence of variety and the year impact on selenium content was not confirmed $(p>0.05)$ (Table 5).

The content of selenium ranged from 9 to $95 \mu \mathrm{g} \cdot \mathrm{kg}^{-1}$. Foliar application of inorganic selenium very significantly increased the content of selenium in basil herb according to the research study by Mezeyová et al. (2016). The most effective here seemed to be the double dose of selenium ( $5 \mathrm{mg} \mathrm{Se} \cdot \mathrm{m}^{-2}$ ) when in 'Red Rubin' was incorporated in $7.859 \pm 0.9 \mathrm{mg} \cdot \mathrm{kg}^{-1}$ of selenium in comparison with $0.058 \pm 0.004 \mathrm{mg} \cdot \mathrm{kg}^{-1}$ (control variant) and in 'Dark Green' $4.017 \pm 0.8 \mathrm{mg} \cdot \mathrm{kg}^{-1}$ in comparison with control value $0.154 \pm 0.05 \mathrm{mg} \cdot \mathrm{kg}^{-1}$. Puccinelli et al. (2019) also tested the ability of basil plants grown in hydroponics to take up Se from the growth substrate and to study the effects of Se concentration on plant growth and Se accumulation. Se concentration increased during

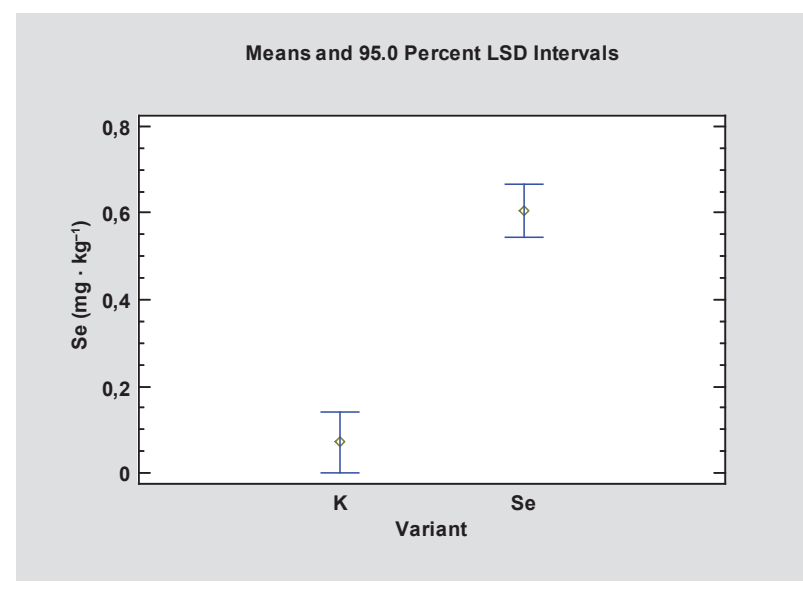

Figure 1. The effect of selenisation on selenium content in basil seeds (d.w.), 2017-2018. K, control variant and Se, selenised variant.

Table 5. Selenium content in basil seeds ( $\mathrm{mg} \cdot \mathrm{kg}^{-1}$ d.w.)

\begin{tabular}{llrr}
\hline & & Control & \multicolumn{1}{c}{ Selenium } \\
\hline \multirow{2}{*}{$2017^{\mathrm{A}}$} & Tulsi & $0.025 \pm 0.004 \mathrm{a}$ & $0.809 \pm 0.051 \mathrm{c}$ \\
& Cinamonette & $0.017 \pm 0.003 \mathrm{a}$ & $0.437 \pm 0.149 \mathrm{~b}$ \\
& Dark Green & $0.020 \pm 0.001 \mathrm{a}$ & $0.370 \pm 0.299 \mathrm{~b}$ \\
\cline { 2 - 3 } $2018^{\mathrm{A}}$ & Tulsi & $0.055 \pm 0.001 \mathrm{a}$ & $0.528 \pm 0.026 \mathrm{~b}$ \\
& Cinamonette & $0.083 \pm 0.003 \mathrm{a}$ & $0.748 \pm 0.048 \mathrm{c}$ \\
& Dark Green & $0.078 \pm 0.001 \mathrm{a}$ & $0.823 \pm 0.055 \mathrm{~d}$ \\
\cline { 2 - 3 } Average (2017-2018) & Tulsi & $0.040 \pm 0.003 \mathrm{a}$ & $0.669 \pm 0.039 \mathrm{~b}$ \\
& Cinamonette & $0.050 \pm 0.003 \mathrm{a}$ & $0.593 \pm 0.099 \mathrm{~b}$ \\
& Dark Green & $0.049 \pm 0.001 \mathrm{a}$ & $0.597 \pm 0.177 \mathrm{~b}$ \\
\hline
\end{tabular}

A, a - Values with different letters are significantly different at $p<0.05$ by LSD test in ANOVA (Statgraphic XVII). 
seedling growth, was highest in younger leaves and then declined before or on flowering.

After application of $5 \mathrm{mg} \mathrm{Se} \cdot \mathrm{m}^{-2}$ in two varieties of peas, 25-fold increase in the selenium content in seeds was reported in comparison with control in the study by Hegedüsová et al. (2015). As lot of other crops such as peas, rice, corn, wheat (Gomez-Galera et al., 2010; Ozkutlu et al., 2011; Poblaciones et al., 2014; Premarathna et al., 2012; Manojlović et al., 2019; Hawkesford and Zhao, 2007; Poblaciones and Rengel, 2018; Fernandes et al., 2014) were positive in test for incorporation of selenium in grains, there was prediction of selenium increasing possibility in basil seeds. In selenised basil seeds, the increase in selenium content in case of Tulsi was 17 -fold in comparison with control variant, 12-fold in 'Cimonette' and 12-fold in 'Dark Green' compared with control.

On the other hand, the optimum dosage of the selenium fertiliser is very important because of possible selenium toxicity in plants. It mainly depends on their ability to divert selenium away from the accumulation of selenocysteine and selenomethionine which ranges from $2 \mathrm{mg} \cdot \mathrm{kg}^{-1}$ in non-accumulators, such as rice, and $330 \mathrm{mg} \cdot \mathrm{kg}^{-1}$ in white clover, to several thousands of $\mathrm{mg} \cdot \mathrm{kg}^{-1}$ in the accumulator Astragalus bisulcatus. Gebreeyessus and Zewge (2019) stated that in nonaccumulators selenium toxicity occurs about $10-100 \mathrm{mg}$ $\mathrm{Se} \cdot \mathrm{kg}^{-1}$ d.w. Ozkutlu et al. (2011) analysed that 26 medicinal and aromatic plants $O$. basilicum, widely used as either a fresh or dried spice, presented the highest Se content with $1,133 \pm 104 \mu \mathrm{g} \cdot \mathrm{kg}^{-1}$ d.w., followed by Peganum harmala L. (951 $\pm 22 \mu \mathrm{g} \cdot \mathrm{kg}^{-1}$ d.w.), aerial parts of Urtica dioica (content $271 \pm 16 \mu \mathrm{g} \cdot \mathrm{kg}^{-1} \mathrm{~d}$.w.) and the seeds of Linum usitatissimum $\left(193 \pm 26 \mu \mathrm{g} \cdot \mathrm{kg}^{-1} \mathrm{~d}\right.$.w.). As the basil is good accumulator of Se, it is also important to observe other important quantitative (yields of herbs or seeds) and qualitative parameters (chlorosis of herbs, interfering with chlorophylls and other antioxidants) which can also be influenced by selenium enrichment.

\section{Antioxidant activity}

The values of AOA reached from $714.22 \%$ inhibition ('Cinamonette', 2018, selenised variant) to $1,061.03 \%$ inhibition ('Tulsi', 2018, selenised variant) as shown in Table 6. The impact of fortification with selenium was not significant $(p>0.05)$ comparing the data from both tested years (Figure 2). There were found some significant $(p<0.05)$ differences in varieties in relation to particular year and variant. The impact of the climatic condition in both tested years did not have significant impact on the trial results (Table 6).

In basil seeds, the selenium content was increased without significant impact $(p>0.05)$ on AOA. In our trial, in some cases selenised variant showed higher values without statistically significance, i.e. in contrast with other authors. The foliar supplementation of selenium and/or AsA, especially the mixed ones, led to significant improvement in antioxidative activities according to Oraghi Ardebili et al. (2015), tested possible impacts of foliar supplementations of Se and/or AsA on basil. Seedlings were foliarly treated with four concentrations of $\mathrm{Se}\left(0,30,60\right.$ and $\left.120 \mathrm{mg} \cdot \mathrm{L}^{-1}\right)$ and/or two levels of AsA (0 and $\left.200 \mathrm{mg} \cdot \mathrm{L}^{-1}\right)$.

According to Sarfraz et al. (2011) total AOA of O. sanctum seed and leaf extract displayed $84.59 \%$ and $79.39 \%$ inhibition activities, respectively. Ocimum sanctum L. leaves reached $73.70 \% \pm 5.87 \%$ by DPPH method in the study by Farrukh et al. (2006). In relation to

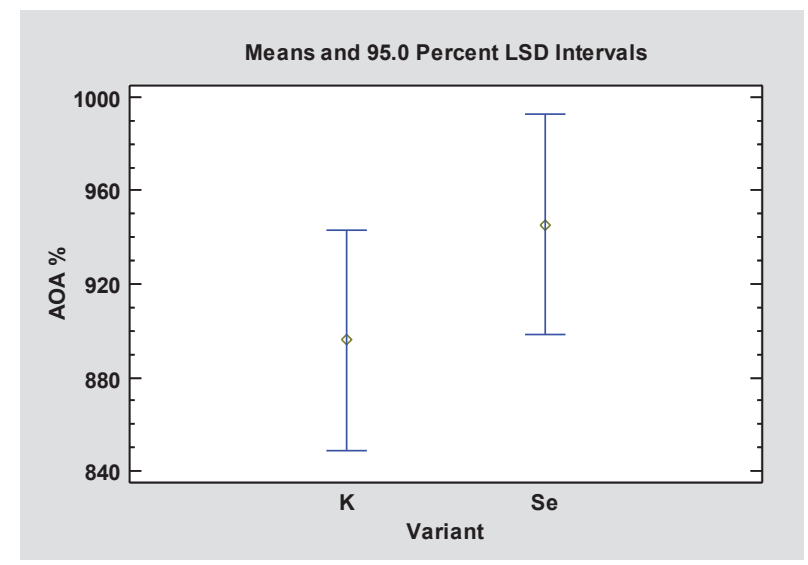

Figure 2. The effect of selenisation on AOA (\% inhibition) in basil seeds (d.w.), 2017-2018. K, control variant and Se, selenised variant.

Table 6. AOA in basil seeds (\% inhibition d.w.)

\begin{tabular}{|c|c|c|c|}
\hline & & Control & Selenium \\
\hline \multirow{3}{*}{$2017^{\mathrm{A}}$} & Tulsi & $861.87 \pm 195.82 \mathrm{a}$ & $1011.91 \pm 97.76 \mathrm{~b}$ \\
\hline & Cinamonette & $857.63 \pm 143.60 \mathrm{a}$ & $922.56 \pm 13.32 \mathrm{ab}$ \\
\hline & Dark Green & $916.67 \pm 121.66 \mathrm{ab}$ & $1032.72 \pm 51.03 \mathrm{~b}$ \\
\hline \multirow{3}{*}{$2018^{\mathrm{A}}$} & Tulsi & $1075.11 \pm 118.02 \mathrm{c}$ & $1061.03 \pm 116.78 \mathrm{c}$ \\
\hline & Cinamonette & $843.34 \pm 93.31 \mathrm{ab}$ & $714.22 \pm 78.17 \mathrm{a}$ \\
\hline & Dark Green & $821.51 \pm 90.50 \mathrm{ab}$ & $932.60 \pm 102.85 \mathrm{bc}$ \\
\hline \multirow{3}{*}{ Average (2017-2018) } & Tulsi & $968.49 \pm 156.92 \mathrm{bc}$ & $1036.47 \pm 107.27 \mathrm{c}$ \\
\hline & Cinamonette & $850.49 \pm 118.45 \mathrm{ab}$ & $818.39 \pm 45.74 \mathrm{a}$ \\
\hline & Dark Green & $869.09 \pm 106.08 \mathrm{ab}$ & $982.66 \pm 76.94 \mathrm{bc}$ \\
\hline
\end{tabular}

A, a - Values with different letters are significantly different at $p<0.05$ by LSD test in ANOVA (Statgraphic XVII). 
seeds, 11 varieties of bean were studied by ArmendárizFernández et al. (2019) and they were classified into three main groups: (1) high levels, (2) medium levels and (3) low levels of antioxidant capacity. Within the high level of antioxidant capacity are the following bean varieties: Sangre de Toro, Blanco Michigan, Pinto Americano and Flor de Mayo. The Sangre de Toro variety has the highest antioxidant capacity $(82.1 \%)$, followed by 'Blanco Michigan' (81.8\%), 'Pinto Americano' (80.6\%) and 'Flor de Mayo' (79.1\%). In comparison to our results, there are differences in AA inhibiton. The problem in the antioxidant capacity determination is that the research laboratories use different methods of determination. Result of measurement depends on the initial DPPH concentration and the chosen reaction time, which has been chosen by the authors. The results are difficult to compare or not comparable at all. Due to the mutual comparison of various agricultural products was calculation of the original Lachman method modified according to Hegedüs et al. (2019), which takes into account the dilution of the extract due to varying antioxidant activities of individual horticultural crops. For comparability of our results with the results of other authors, we also expressed the AOA results as TEAC. Total AOA varied from $26.26 \mathrm{mmol}$ Trolox $\cdot \mathrm{kg}^{-1}$ d.w. ('Dark Green') to $28.67 \mathrm{mmol}$ Trolox $\cdot \mathrm{kg}^{-1} \mathrm{~d}$.w. ('Tulsi') in controlled variant and from $23.50 \mathrm{mmol}$ Trolox $\cdot \mathrm{kg}^{-1}$ d.w. ('Cinamonette') to $28.97 \mathrm{mmol}$ Trolox $\cdot \mathrm{kg}^{-1}$ d.w. ('Tulsi') in selenised variant when following the average of both tested years (Table 7). Influence of selenisation on TEAC was not confirmed as shown in Figure $3(p>0.05)$. Similarly, in the study by Mezeyová et al. (2016), in selenised variant significant influence of variety was found whereas Purple Ruffles variety reached significantly lower TEAC $(p<0.05)$ in comparison with 'Dark Green' and 'Tulsi'. Total AOA varied from 10.8 to $35.7 \mu \mathrm{mol} \mathrm{TE} \cdot \mathrm{g}^{-1} \mathrm{~d}$.w. in Dezful I and Babol accessions, respectively, in the study by Javanmardi et al. (2003) as they determined total AOA in 23 Iranian basil accessions as micromoles of Trolox equivalents per gram of dry weight. To compare AOA with the seeds of basil was difficult so far as there were not scientific studies oriented to this kind of topic. According to Cherian (2019) the basil seeds are often underutilised, despite having a high concentration of powerful compounds and active ingredients that can impact human health. Some of the key active ingredients in basil seeds are dietary fibre, vitamin $\mathrm{K}$, iron, protein, phytochemicals, polyphenolic flavonoids like orientin and vicenin and other powerful antioxidants. Their gelatin-like consistence in fluid started to be interesting and comparable with chia seeds. In the study by Marineli et al. (2014), the commercial chia seeds from Chile were chemically and nutritionally characterised and were investigated for their antioxidant potential by different in vitro methods. Average TEAC was estimated $523.78 \mu \mathrm{mol}$ Trolox $\cdot \mathrm{g}^{-1}$. All the methods evaluated in their study provided quite similar results to the ones reported by Capitani et al. (2012) for Argentina chia meals $\left(557.2 \mu \mathrm{mol}\right.$ Trolox $\left.\cdot \mathrm{g}^{-1}\right)$ and fibrous fractions (446.4 $\mu \mathrm{mol}$ Trolox $\cdot \mathrm{g}^{-1}$ ) obtained by pressing extraction and by Vázquez-Ovando et al. (2009) for a Mexican chia fibrous fraction $\left(488.8 \mu \mathrm{mol}\right.$ Trolox $\left.\cdot \mathrm{g}^{-1}\right)$. Comparing the selenisation influence on AOA of basil seeds with other authors is very difficult, because of the absence of scientific studies. The importance of agrological technologies was confirmed by Falco et al. (2018), where the AOA of chia seed was negatively affected by irrigation and ranged from $1.317 \pm 0.027$ to $2.174 \pm 0.010 \mathrm{mmol}$ Trolox $\cdot \mathrm{g}^{-1}$.

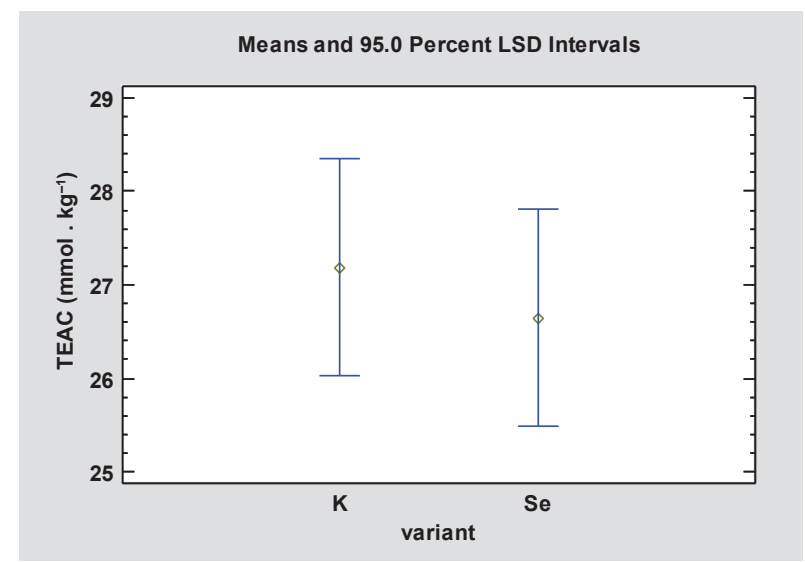

Figure 3. The effect of selenisation on AOA (mmol Trolox $\cdot \mathrm{kg}^{-1}$ ) in basil seeds (d.w.), 2017-2018. K, control variant and Se, selenised variant.

Table 7. AOA in basil seeds (mmol Trolox $\cdot \mathrm{kg}^{-1} \mathrm{~d}$.w.)

\begin{tabular}{llll}
\hline & & \multicolumn{1}{c}{ Control } & Selenium \\
\hline \multirow{2}{*}{$2017^{\mathrm{A}}$} & Tulsi & $27.43 \pm 3.90 \mathrm{bc}$ & $27.63 \pm 2.23 \mathrm{bc}$ \\
& Cinamonette & $27.43 \pm 2.83 \mathrm{bc}$ & $25.60 \pm 0.26 \mathrm{abc}$ \\
& Dark Green & $28.57 \pm 2.41 \mathrm{c}$ & $28.10 \pm 1.15 \mathrm{c}$ \\
\cline { 2 - 4 } $2018^{\mathrm{A}}$ & Tulsi & $29.90 \pm 3.61 \mathrm{c}$ & $30.30 \pm 3.63 \mathrm{c}$ \\
& Cinamonette & $26.50 \pm 3.22 \mathrm{bc}$ & $21.40 \pm 2.61 \mathrm{a}$ \\
& Dark Green & $23.95 \pm 2.90 \mathrm{ab}$ & $26.85 \pm 3.25 \mathrm{bc}$ \\
\cline { 2 - 4 } Average (2017-2018) & Tulsi & $28.67 \pm 3.76 \mathrm{~b}$ & $28.97 \pm 2.93 \mathrm{~b}$ \\
& Cinamonette & $26.97 \pm 3.02 \mathrm{ab}$ & $23.50 \pm 1.44 \mathrm{a}$ \\
& Dark Green & $26.26 \pm 2.66 \mathrm{ab}$ & $27.48 \pm 2.20 \mathrm{~b}$ \\
\hline
\end{tabular}

A, a - Values with different letters are significantly different at $p<0.05$ by LSD test in ANOVA (Statgraphic XVII). 
Table 8. TPC in basil seeds ( $\mu \mathrm{g} \mathrm{GA} \cdot \mathrm{g}^{-1}$ d.w.)

\begin{tabular}{llll}
\hline & & \multicolumn{1}{c}{ Control } & Selenium \\
\hline \multirow{2}{*}{$2017^{\mathrm{A}}$} & Tulsi & $1188.74 \pm 112.16 \mathrm{a}$ & $1270.15 \pm 318.06 \mathrm{a}$ \\
& Cinamonette & $1766.68 \pm 391.88 \mathrm{ab}$ & $1573.24 \pm 355.33 \mathrm{ab}$ \\
& Dark Green & $1996.16 \pm 214.47 \mathrm{~b}$ & $1540.95 \pm 316.67 \mathrm{ab}$ \\
\cline { 2 - 3 } $2018^{\mathrm{A}}$ & Tulsi & $1824.35 \pm 41.02 \mathrm{~b}$ & $1559.08 \pm 21.01 \mathrm{a}$ \\
& Cinamonette & $1368.52 \pm 19.62 \mathrm{a}$ & $1449.95 \pm 24.59 \mathrm{a}$ \\
& Dark Green & $1367.35 \pm 25.01 \mathrm{a}$ & $1462.71 \pm 28.44 \mathrm{a}$ \\
\cline { 2 - 3 } Average (2017-2018) & Tulsi & $1506.55 \pm 76.59 \mathrm{a}$ & $1414.61 \pm 169.54 \mathrm{a}$ \\
& Cinamonette & $1567.60 \pm 205.75 \mathrm{a}$ & $1511.60 \pm 189.96 \mathrm{a}$ \\
\hline
\end{tabular}

A, a - Values with different letters are significantly different at $p<0.05$ by LSD test in ANOVA (Statgraphic XVII).

\section{Total polyphenol content}

The content of polyphenols in average ranges from $1414.61 \mu \mathrm{g}$ GA $\cdot \mathrm{g}^{-1}$ d.w. ('Tulsi', selenised variant) to $1681.75 \mu \mathrm{g} \mathrm{GA} \cdot \mathrm{g}^{-1}$ d.w. ('Dark Green', control) as shown in Table 8 . Statistical significance of variety was confirmed $(p<0.05)$ evaluating every year, but in average of 2 years this difference was not significant. Influence of the year on TPC was also not found $(p>0.05)$.

Total phenolic content ranged from 22.9 to $65.5 \mathrm{mg}$ $\mathrm{GA} \cdot \mathrm{g}^{-1}$ d.w. in 23 Iranian basil accessions according to Javanmardi et al. (2003) as they determined total phenolic contents by using a spectrophotometric technique based on the Folin-Ciocalteu reagent. In frozen sample of Cinnamon, basil leaves were found $4.4 \pm 0.1$ (mg CAE $\cdot \mathrm{g}^{-1}$ fresh weight) according to Abramovič et al. (2018). Regarding the total phenolic content in seeds, Marineli et al. (2014) found out in chia seeds samples from Chile $0.94 \mathrm{mg} \mathrm{GA} \cdot \mathrm{g}^{-1}$, which was similar to previous reports Reyes-Caudillo et al. (2008), where chia seed from two different regions in Mexico showed values between 0.88 and $0.92 \mathrm{mg}$ $\mathrm{GA} \cdot \mathrm{g}^{-1}$. In climate conditions of Slovakia, it has not been possible to grow the seeds of Salvia hispanica so chia has to be imported. On the other hand, the basil seeds are easily grown and fully matured. According to Pérez-Jiménez et al. (2010), dried sweet basil has $322 \mathrm{mg} \cdot 100 \mathrm{~g}$ of total polyphenols and it is sorted at 26th place within the 100 richest food sources. In Figure 4, average values in case of control are lower compared with selenised variant but this difference was not statistically significant $(p>0.05)$. The effort to compare the influence of selenisation on TPC with other authors was not successful as this question was not solved in the seeds of basil. Impact of selenium fortification on Se accumulation and total polyphenols was tested in grains of pea in Hegedüsová et al. (2017). The significantly positive influence of Se application on the total polyphenols content (TPC) has been confirmed in two pea varieties after application of dosage in $100 \mathrm{~g}$ $\mathrm{Se} / \mathrm{ha}(52 \%$ and $33 \%)$. TPC ranged in interval from 1471 to $2236 \mathrm{mg} \mathrm{GA} \cdot \mathrm{kg}^{-1}$ d.w. for Ambassador variety and from 1417 to $1880 \mathrm{mg} \mathrm{GA} \cdot \mathrm{kg}^{-1} \mathrm{~d}$.w. for 'Premium' in dependence on observed variant.

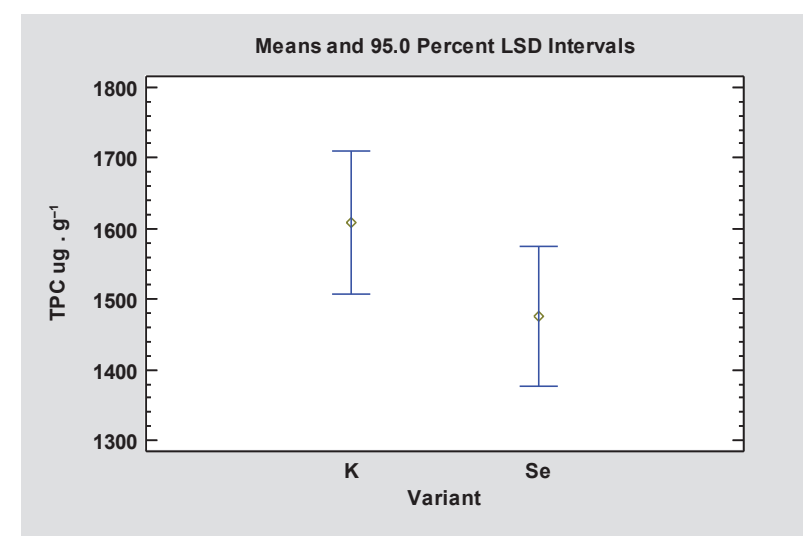

Figure 4. The effect of selenisation on TPC in basil seeds (d.w.), 2017-2018. K, control variant and Se, selenised variant.

\section{CONCLUSIONS}

Applied dose of sodium selenate at a concentration of $5 \mathrm{mg} \mathrm{Se} \cdot 1 \mathrm{~m}^{-2}$ had a positive effect on increasing the selenium content in the seed of basil and it did not have significant effect $(p>0.05)$ on other assayed quality parameters (AA, TPC). By incorporating selenium, its nutritional value was increased about additional antioxidant. By consuming $9 \mathrm{~g}$ selenised basil seeds (in comparison with $120 \mathrm{~g}$ of seeds without fortification), the daily recommended dose of selenium could be covered for human beings. Since the popularity of Lamiaceae seeds has rising tendency in raw consummation and because of gelatin-like consistence in fluid, it is considered to be an interesting way of dietary enrichment. Since basil has a very high germination rate and is successfully germinated in this way, selenised seed can be a secondary reservoir of selenium for cultivated green matter which is a subject for further studies.

\section{FUNDING}

This research was funded by Scientific Grant Agency of the Ministry of Education, Youth and Sports of the Slovak Republic by grant number 1/0087/17. 


\section{AUTHOR CONTRIBUTIONS}

I.M. and A.H.: conceptualisation. I.M., A.H. and O.H.: methodology. O.H., A.V., M.T. and J.M.: laboratory analyses. A.A. and T.J.: investigation, editing, I.M. and A.H.: writing, review and editing. M.Š. and J.M.: funding acquisition. All authors read and approved the final manuscript.

\section{CONFLICT OF INTEREST}

The authors declare no conflict of interest.

\section{REFERENCES}

Abramovič, H., Abram, V., Čuk, A., Čeh, B., Možina, S., Vidmar, M, Pavlovic, M., And Ulrih, N. P. (2018). Antioxidative and antibacterial properties of organically grown thyme (Thymus sp.) and basil (Ocimum basilicum L.). Turkish Journal of Agriculture and Forestry, 42, 185-194.

Andrejiová, A., Hegedüsová, A., Adamec, S., Hegedüs, O., And Mezeyová, I. (2019). Increasing of selenium content and qualitative parameters in tomato (Lycopersicon esculentum Mill.) after its foliar application. Potravinárstvo Slovak Journal of Food Sciences, 13(1), 351-358.

Armendáriz-Fernández, K. V., Herrera-Hernández, I. M., Muñoz-Márquez, E., And SÁnchez, E. (2019). Characterization of bioactive compounds, mineral content, and antioxidant activity in bean varieties grown with traditional methods in Oaxaca, Mexico. Antioxidants, 8(1), 26.

Bouis, H. E., And Saltzman, A. (2018). Improving nutrition through biofortification: A review of evidence from Harvest Plus, 2003 through 2016. Global Food Security, 12, 49-58.

Capitani, M. I., Spotorno, V., Nolasco, S. M., and TomÁs, M. C. (2012). Physicochemical and functional characterization of by-products from chia (Salvia hispanica L.) seeds of Argentina. LWT - Food Science and Technology, 45(1), 94-102.

Cherian, R. P. (2019). Health benefits of basil seeds. International Journal of Scientific Research in Science, Engineering and Technology, 6(2), 511-515.

Díaz-Gómez, J., Twyman, R. M., Zhu, C. H., Farre, G., Serrano, J. C. E., Portero-Otin, M., Muñoz, P., Sandmann, G., Capell, T., and Christou, P. (2017). Biofortification of crops with nutrients: Factors affecting utilization and storage. Current Opinion in Biotechnology, 44, 115-123.

Elmadfa, I., ANd Weichselbaum, E. (EDS) (2009). European nutrition and health report Karger. Forum of Nutrition, 62, $412 \mathrm{p}$.

European Food Safety Authority. (2014). Scientific opinion on dietary reference values for selenium. European Food Safety Authority Journal, 12(10), 3846.

Falco, B., Fiore, A., Bochicchio, R., Amato, M., And LAnzotti, V. (2018). Metabolomic analysis by UAE-
GC MS and antioxidant activity of Salvia hispanica (L.) seeds grown under different irrigation regimes. Industrial Crops and Products, 112, 584-592.

Farrukh, A., IQbal, A., AND Zafar, M. (2006). Antioxidant and free radical scavenging properties of twelve traditionally used Indian medicinal plants. Turkish Journal of Biology, 30, 177-183.

Fašiangová, M., BoŘilová, G., And Hulánková, R. (2017). Effect of dietary Se supplementation on the Se status and physico-chemical properties of eggs A review. Czech Journal of Food Sciences, 35(4), 275-284.

Fernandes, K. F. M., Berton, R. S., And Coscione, A. R. (2014). Selenium biofortification of rice and radish: Effect of soil texture and efficiency of two extractants. Plant Soil Environment, 60(3), 105-110.

Gebreeyessus, G. D., And Zewge, F. (2019). A review on environmental selenium issues. SN Applied Science, 1,55 .

Gomez-Galera, S., Rojas, E., Sudhakar, D., Zhu, C. F., Pelacho, A. M., Capell, T., And Christou, P. (2010). Critical evaluation of strategies for mineral fortification of staple food crops. Transgenic Research, 19(2), 165-180.

Hawkesford, M. J., AND ZhaO, F. J. (2007). Strategies for increasing the selenium content of wheat. Journal of Cereal Science, 46(3), 282-292.

HAWrylak-NowaK, B. (2008). Enhanced selenium content in sweet basil (Ocimum basilicum L.) by foliar fertilization. Vegetable Crops Research Bulletin, 69, 63-72.

Hegedüs, O., Hegedüsová, A., Szarka, K., Šlosár, M., AND MaŤovÁ, A. (2019). Antioxidant activity determination of horticultural crops. Proceedings of 19th International Multidisciplinary Scientific GeoConference SGEM 2019, Vol. 19, (pp. 543-55), Albena, Bulgaria: SGEM.

Hegedüsová, A., Mezeyová, I., Hegedüs, O., Andrejiová, A., Juríková, T., Golian, M., And LoŠÁK, T. (2017). Increasing of selenium content and qualitative parameters in garden pea (Pisum sativum L.) after its foliar application. Acta Scientiarum Polonorum - Hortorum Cultus, 16, 3-17.

Hegedüsová, A., Mezeyová, I., Hegedüs, O., Musilová, J., and Paulen, O. (2015). Selenium content increasing in the seeds of garden pea after foliar biofortification. Potravinárstvo Slovak Journal of Food Sciences, 9(1), 434-441.

Hreško, J., Pucherová, Z., And Baláž, I. (2006). The Nitra Region and its surroundings: Initial stage of research (1st ed., p. 181). Nitra, Slovak Republic: Constantine the Philosopher University in Nitra.

Javanmard, J., Stushnoff, C., Locke, D., And Vivanco, J. M. (2003). Antioxidant activity and total phenolic content of Iranian Ocimum accessions. Food Chemistry, 83(4), 154-196.

Lachman, J., ProněK, D., Hejtmánková, A., Dudjak, J., Pivec, V., And Faitová, K. (2003). Total polyphenol 
and main flavonoid antioxidants in different onion (Allium cepa L.) varieties. Horticultural Science, 30(4), 142-147.

Manojlović, M. S., Lončarić, Z., Cabilovski, R. L., AND Singh, B. L. (2019). Biofortification of wheat cultivars with selenium. Acta Agriculturae Scandinavica, 69(8), 715-724.

Marineli, R. S., Moraes, É.A., Lenquiste, S. A., Godoy, A. T., Eberlin, M. N., and Maróstica, M. R. (2014). Chemical characterization and antioxidant potential of Chilean chia seeds and oil (Salvia hispanica L.). LWT - Food Science and Technology, 59(2), 1304-1310.

Melicháčová, S., Timoracká, M., Bystrická, J., AND Vollmannoví, A. (2010). Relation of total antiradical activity and total polyphenol content of sweet cherries (Prunus avium L.) and tart cherries (Prunus cerasus L.). Acta Agriculturae Slovenica, 95(1), 21-28.

Mezeyová, I., Hegedüsová, A., Andrejiová, A., Hegedüs, O., and Golian, M. (2016). Phytomass and content of essential oils in Ocimum basilicum after foliar treatment with selenium. Agriculture and Food, 4, 19-27.

Mezeyová, I., Hegedüsová, A., Hegedüs, O., Farkaš, J., AND ŠLOSÁR, M. (2018). Qualitative parameters of less grown basils depending on nutrition in the form selenium. International Journal of Agriculture, Forestry and Life Sciences, 2, 164-170.

Muráriková, A., AND Neugebauerová, J. (2018). Seasonal variation of ascorbic acid and nitrate levels in selected basil (Ocimum basilicum L.) varieties. Horticultural Science (Prague), 45, 47-52.

Oraghi Ardebili, N., Jalili, S., and Safiallah, S. (2015). The modified qualities of basil plants by selenium and/or ascorbic acid. Turkish Journal of Botany, 39, 401-407.

Ozkutlu, F., Sekeroglu, N., Koca, U., and Yazici, G. (2011). Selenium concentrations of selected medicinal and aromatic plants in Turkey. Natural Product Communication, 6, 1469-1472.

Pérez-Jiménez, J., Neveu, V., Vos, F., and Scalbert, A. (2010). Identification of the 100 richest dietary sources of polyphenols: An application of the Phenol-Explorer database. European Journal of Clinical Nutrition, 64(3), 112-120.

Poblaciones, M. J., And Rengel, Z. (2018). The effect of processing on Pisum sativum L. biofortified with sodium selenate. Journal of Plant Nutrition and Soil Science, 181(6), 932-937.

Poblaciones, M. J., Rodrigo, S., Santamaría, O., Chen, Y., and Grath, S. P. (2014). Agronomic selenium biofortification in Triticum durum under Mediterranean conditions: From grain to cooked pasta. Food Chemistry, 146(1), 378-384.
Premarathna, L., Mclaughlin, M. J., Kirby, J. K., Hettiarachchi, G. M., Stacey, S., and Chittleborough, D. J. (2012). Selenate enriched urea granules are a highly effective fertilizer for selenium biofortification of paddy rice grain. Journal of Agricultural and Food Chemistry, 60(23), 6037-6044.

Puccinelli, M., Malorgio, F., Rosellini, I., AND Pezzarossa, B. (2017). Uptake and partitioning of selenium in basil (Ocimum basilicum L.) plants grown in hydroponics. Scientia Horticulturae, 225, 271-276.

Puccinelli, M., Malorgio, F., Rosellini, I., AND Pezzarossa, B. (2019). Production of seleniumbiofortified microgreens from selenium-enriched seeds of basil. Journal of the Science of Food and Agriculture, 99(12), 5601-5605.

Rayman, M. P. (2012). Selenium and human health. The Lancet, 379(9822), 1256-1268.

Reyes-Caudillo, E., Tecante, A., and Valdivia-López, M. A. (2008). Dietary fibre content and antioxidant activity of phenolic compounds present in Mexican chia (Salvia hispanica L.) seeds. Food Chemistry, 107(2), 656-663.

Rothery, E., AND BeAch, L. (1988). Analytical methods for graphite tube atomizers (p. 226). Mulgrave, VIC: Varian Australia Pty Ltd.

Sarfraz, Z., Anjum, F. M., Khan, M. I., Arshad, M. S., AND NADEEM, M. (2011). Characterization of basil (Ocimum basilicum L.) parts for antioxidant potential. African Journal of Food Science and Technology, 2, 204-213.

Smoleń, S., Skoczylas, Ł., Ledwożyw-Smoleń, I., Rakoczy, R., Kopeć, A., Piątkowska, E., Bieżanowska-Kopeć, R., Koronowicz, A., And Kapusta-Duch, J. (2016). Biofortification of carrot (Daucus carota L.) with iodine and selenium in a field experiment. Frontiers in Plant Science, 7, 730.

Stanojevic, L. P., Marjanovic-Balaban, Z. R., Kalaba, D. V., Stanojevic, J. S., Cvetkovic, D. J., AND CAKIC, M. D. (2017). Chemical composition, antioxidant and antimicrobial activity of basil (Ocimum basilicum L.) essential oil. Journal of Essential Oil-Bearing Plants, 20(6), 1557-1569.

Vázquez-Ovando, A., Rosado-Rubio, G., ChelGuerrero, L., and Betancur-Ancona, D. (2009). Physicochemical properties of a fibrous fraction from chia (Salvia hispanica L.). LWT-Food Science and Technology, 4(1), 168-173.

Zoidis, E., Seremelis, I., Kontopoulos, N., And Danezis, G. P. (2018). Selenium-dependent antioxidant enzymes: Actions and properties of selenoproteins. Antioxidants, 7(5), 1-26.

Received February 12, 2020; accepted February 21, 2020 